\title{
Contributions of The Medusae of Phyllorhiza punctata (Scyphozoa: Rhizostomae) in Production of Dissolved Organic Carbon (DOC)
}

\author{
Kontribusi Medusae Phyllorhiza punctata (Scyphozoa: Rhizostomae) Dalam Produksi \\ Karbon Organik Terlarut (KOT)
}

\section{A.Wahab Jufri}

Program Studi Pendidikan Biologi FKIP Universitas Mataram

Jln. Majapahit No. 62 Mataram, Lombok

Telp : 0370623873 email :ejufri@yahoo.com

\begin{abstract}
Abstrak
Medusa Phyllorhiza punctata mampu menghasilkan lendir yang dapat diserap oleh molekul organik serta berperan sebagai agregat atau sumber energi bagi pertumbuhan dan perkembangan bakteri. Penelitian ini telah dilaksanakan dengan tujuan untuk mengetahui pola produksi karbon organik terlarut (KOT) oleh medusa P.punctata dan untuk mendeterminasi hubungan antara produksi KOT dengan produksi dan konsumsi oksigen dalam proses fotosintesis. Hasil penelitian menunjukkan bahwa medusa yang berukuran kecil (berat basah $<7$ gram) menghasilkan oksigen lebih banyak dari jumlah yang dibutuhkan. Sedangkan medusa yang berukuran lebih besar mengkonsumsi oksigen lebih banyak dari jumlah yang dihasilkan. Secara individual, medusa dengan berat antara 4 - 6,8 gram dapat memproduksi karbon organik terlarut sebesar $27,44 \mathrm{mg}$ karbon per hari dan medusa yang berukuran besar dengan berat 27 - 45 gram dapat menghasilkan KOT sekitar 308,7 mg karbon per hari.
\end{abstract}

Kata kunci : Phyllorhiza punctata, KOT, oksigen, medusa.

Diterima: 12 Februari 2004, disetujui: 03 Maret 2004

\section{Introduction}

Dissolved organic carbon (DOC) from a variety of sources, including zooplankton grazing, cell lysis and algal exudation, is a major substrate for pelagic bacterial production (Sondergaard et al., 1995). DOC also derives from gelatinous zooplankton as they produce mucus (Hamner et al., 1975; Porter et al., 1984) which may be lost to the pelagic environment as aggregates or in dissolved form. Mucus aggregates may also absorb dissolved organic molecules and serve as nuclei for aggregate enlargement by bacteria (Alldredge, 1976). In a given volume of water, coral mucus aggregates have been shown to contain more particulate organic carbon $(10 \mathrm{x})$ and more particulate organic nitrogen $(20 \mathrm{x})$ than occurred in filterable particles (Coles and Strathmann, 1973).

The scyphomedusa Aurelia aurita produces mucus which has a central role in the predation process. Individual medusae of $A$. aurita from the Skagerrak Gullmars Fjorde, Sweden, ranging from 9.5 to $18 \mathrm{~cm}$ in diameter, released DOC at an average rate of $1.2 \mathrm{mg}$ C. day $^{-1}$ (Hanson and Norman, 1995). The main source of this DOC is likely to be the mucus which is produced in obviously copious quantities (Schneider, 1989). Hanson and Norman (1995) found that carbon released by the medusae of Aurelia aurita had a positive effect on bacterial growth. In the Baltic sea, the peak of bacterial production occurs in the summer season, at the same time as the peak of Aurelia aurita abundance (Larson and Hagström, 1982). 
For those cnidaria which live symbiotically with zooxanthellae, the production and release of mucus and DOC is probably far more significant than for cnidaria which lack zooxanthellae. Zooxanthellae may be photosynthetically active and produce more oxygen than is consumed by the host and the algae (Fitt et al., 1982), and photosynthates made available by the algae may be exceed the host's daily requirement of carbon (Hofmann and Kremer, 1981). Examples of this have been shown for the coral Styllopora pistillata (Muscatine, et al 1989) for the scyphomedusa Linuche unguiculata (Kremer, et al 1990) and for a nudibranch Pteraeolidia ianthina (HoeghGuldberg and Hinde, 1986). Varying proportions of the carbon fixed by zooxanthellae are translocated and either used by the host or lost to the external environment. For the coral Styllopora pistillata, all of the carbon required for respiration and growth could be supplied by the zooxanthellae (McCloskey and Muscatine, 1984) although it assimilates only about $8 \%$ of the total carbon fixed and translocated by the symbiont (Falkowski et al., 1984). Respiration and growth of zooxanthellae in L. unguiculata used only $21 \%$ of the carbon fixed by photosynthesis, leaving $79 \%$ to be translocated to the animal host (Kremer et al., 1990), while for $P$. ianthina the host received $25-50 \%$ of the total carbon within one hour of being fixed by the zooxanthellae (Hoegh-Guldberg and Hinde, 1986).

In those cases where carbon is translocated from zooxanthellae to a host in excess of the host's requirements for respiration and growth, carbon released as mucus or DOC may provide a resource for consumers in the community (Hofmann and Kremer, 1981) The potential ecological significance of this has been shown for the lake habitat of the scyphomedusa Mastigias sp. in Palau. Here, exudates from the medusae of Mastigias sp. have been shown to contribute about $16 \%$ of the total primary production of the lake (McCloskey et al., 1994).

As for other cnidaria with zooxanthellae, the host-symbiont system of the medusae of $P$. punctata could be a net producer of oxygen (Coleman, 1987). This implies a net gain of high energy photosynthates and indicates that the zooxanthellae may play an important role for the animal host, especially in term of energy supply (Mulvay, 1988).

As stated above, apart from the excessive production of DOC from zooxanthellae photosynthates, symbiotic medusae also produce mucus when feeding. Therefore it is plausible that the medusae of $P$. punctata release more DOC than the $1.2 \mathrm{mg}$. ind. ${ }^{-1}$.day ${ }^{-1}$ shown for Aurelia aurita ranging between 9.5 to $18 \mathrm{~cm}$ in diameter (Hansson and Norman, 1995). The objectives of this study were to quantify the release of dissolved organic carbon by the medusae of $P$. punctata and to determine the correlation between dissolved organic carbon (DOC) released and oxygen production and consumption.

\section{Methods}

Medusae of $P$. punctata were collected from the surface water of the Swan-Canning estuary, Western Australia. Individual medusae were carefully removed from the water in a plastic bucket. The medusae were transported to the laboratory with $15 \mathrm{~L}$ of estuary water with salinity abaut $3 \mathrm{ppm}$ in white plastic buckets and used for experiments within 1 hour after collection. Medusae with wet mass ranging from 4 to 45 grams were incubated in semi-transparent polyethylene buckets containing 1.8 litres estuary water for the first experiment and sea water filtered through 10 $\mu \mathrm{m}$ mesh for the second experiment. The medusae were distributed into four groups according to its wet weight. For the small medusae (wet weight $<7$ grams) two to three animals were pooled in each experimental container. Larger medusae (wet weight >27 grams) were incubated individually. In each experiment two to four replicates were provided for each medusae size and two containers without medusae were provided as controls. 


\section{Measurements of oxygen production and consumption.}

Oxygen production and consumption rates for medusae of $P$. punctata were determined by measuring the change in dissolved oxygen in the water in which the animals were held. Dissolved organic carbon released by the medusae was determined as Biological Oxygen Demand (BOD) in samples of water from experimental containers in which animals had been held. BOD was measured in BOD bottles $(150 \mathrm{~mL})$ which were incubated in darkness for five days. Before filling, each water sample was aerated at $23^{\circ} \mathrm{C}$ until $95 \%$ oxygen saturation was reached. Oxygen concentration was measured with a polarygraph probe (YSI model Oxy 320). To measure oxygen consumption and DOC release, medusae were held in darkness in sealed containers with water initially $95 \%$ oxygen saturated. After one hour, the level of dissolved oxygen was measured and samples taken for measurement of BOD. To measure the relation between oxygen production and DOC release the medusae from the first incubation were again incubated, but now in room lighting for one hour. Procedures were repeated as above. Finally, the water outside the medusae tissue was then absorbed with paper tissue, and the wet weight of medusae was recorded with an electronic balance (ER-180A).

\section{Measurement of chlorophyll a}

Medusae from each size group were homogenised in a Solver-Omni mini-blender and samples of homogenate taken for measurement of the number of algal cells and chlorophyll $a$ content. The number of algal cells were counted on a haemocytometer under a stereo microscope. Pigments were extracted by a modification of a method that is usually used for measurement of phytoplankton chlorophyll (ISO, 1992). About $1 \mathrm{~mL}$ volume of homogenised medusae was placed in centrifuge tubes containing $9 \mathrm{~mL}$ of $100 \%$ alcohol to attain $90 \%$ in respect to ethanol. The mixture was gently shaken and placed in a water bath set at $75{ }^{\circ} \mathrm{C}$ for five minutes. The tubes were removed, shaken gently and allowed to cool for ten minutes in darkness and then centrifuged for five minutes at $3000 \mathrm{rpm}$. The absorbency was measured at $\lambda=663$ and $\lambda=750$ before and after acidification.

The chlorophyll $a$ content was calculated using the formula:

Chlo. $a\left(\mu \mathrm{g} . \mathrm{mL}^{-1}\right)=29.6(\mathrm{~A} 663 \mathrm{o}-\mathrm{A} 663 \mathrm{a}) \mathrm{x}$ $10 / 1$. where :

- A663o = A663 nm before acid - 750nm before acid

- A663a = A663 nm after acid - A750nm after acid

$-10 / 1=10 \mathrm{~mL}$ of extract divided by the one $\mathrm{mL}$ sample.

\section{Estimation of DOC released.}

Oxidation of dissolved organic carbon exudates in BOD bottles is assumed to follow the equation:

$\mathrm{D} \mathrm{O} \mathrm{C}+\mathrm{O}_{2} \rightarrow \mathrm{CO}_{2}+$ energy (bacterial

production) $+\mathrm{H}_{2} \mathrm{O}$

Each atom of carbon requires one molecule of oxygen. From the ratio of molecular weights the amount of DOC in the water sample was estimated from the amount of oxygen depletion during incubation. The amount of respirable DOC or $\mathrm{mg} \mathrm{C}$ in $\mathrm{DOC}=$ mg $\mathrm{O}_{2}$ depleted x 12/32.

\section{Results and Discussion}

\section{Chlorophyll a concentration of the medusae}

Wet weight-specific chlorophyll- $a$ concentration and number of zooxanthellae cells decreased as the medusae size increased (Table 1)

\section{Oxygen production and consumption}

Figure 1 shows the pattern of oxygen production and oxygen consumption by the same medusae during one hour of incubation in light and darkness. It is clear that the small medusae produced more oxygen than they consumed. In contrast, the amount of oxygen consumed by the larger medusae was higher than oxygen production. 
Initial concentration of BOD in the first trial when filtered estuary water was used as the incubation medium was $1.9 \mathrm{mg} \mathrm{C} \mathrm{L}^{-1}$ and in the second trial (using filtered sea water) was 0.9 $\mathrm{mg} \mathrm{CL}{ }^{-1}$. These initial BOD levels were subtracted from the BOD of experimental water to calculate the level of DOC released by the medusae. Figure 2 shows the DOC produced by medusae during incubation in room lighting and in darkness. The amount of DOC released by the medusae during incubation in light was higher than that of the same medusae when incubated in darkness.

Table 1. Chlorophyll a concentration, and number of zooxanthellae in the medusae of different size.

\begin{tabular}{ccc}
\hline \hline Medusae wet mass (grams) & Chlorophyll $a\left(\mu \mathrm{g} . \mathrm{mL}^{-1}\right)$ & $\begin{array}{c}\text { No of algal cells } \mathrm{mL}^{-1} \\
\left(\mathrm{x} 10^{4}\right)\end{array}$ \\
\hline \hline 4.36 & 16.58 & 6.9 \\
4.5 & 23.1 & 8.8 \\
6.54 & 19.83 & 9.2 \\
6.25 & 13.31 & 4.53 \\
6.27 & 17.17 & 5.41 \\
6.82 & 23.68 & 8.9 \\
27.76 & 13.9 & 4.2 \\
30.67 & 10.656 & 4.42 \\
35.80 & 11.544 & 4.56 \\
38.64 & 7.69 & 3.54 \\
40.55 & 9.176 & 3.47 \\
43.28 & 9.47 & 3.8 \\
45.68 & 6.216 & 2.94 \\
\hline
\end{tabular}

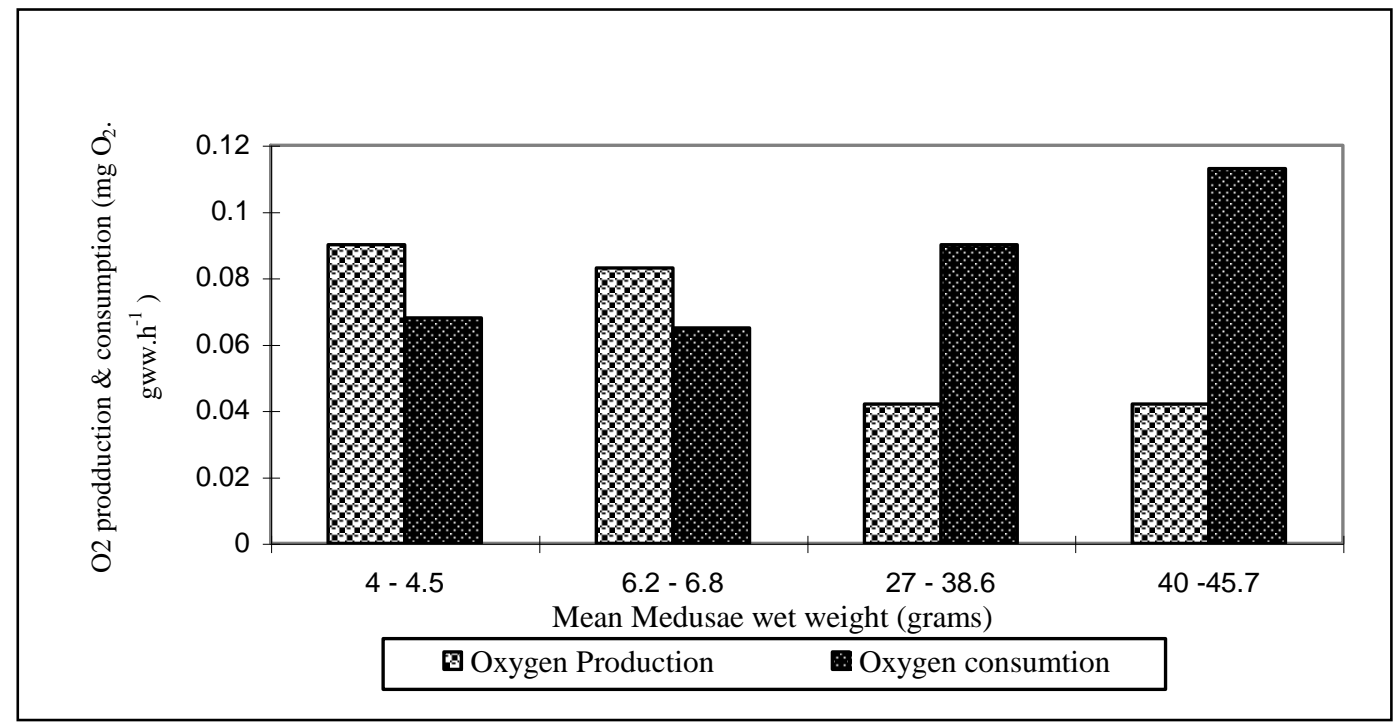

Figure 1. The relations between mean wet mass of medusae with mean oxygen production and consumption. 


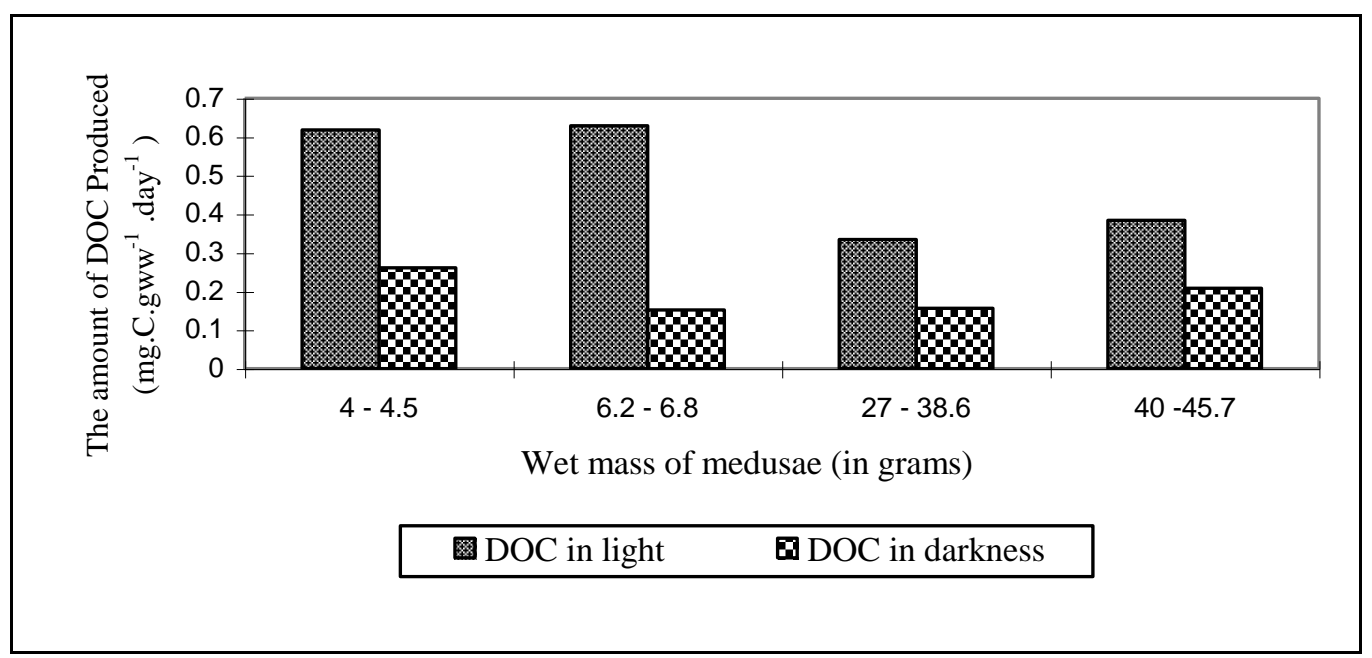

Figure 2. The relation between medusae wet weight with the amount of DOC produced during incubation in room lighting and in darkness.

The presence of symbiotic zooxanthellae in $P$. puntata provides clear benefits to the animal host. These benefits include supply of oxygen, supply of carbohydrate and removal of nitrogenous wastes. Previous studies have shown that carbohydrate produced by algal photosynthesis often exceeds the requirement of both algae (McCloskey et al., 1994) and the animal host. This excess of carbohydrate is released to the surrounding water.

Results of this study suggest that when small medusae were held in room lighting, the zooxanthellae were photosynthetically active and produced oxygen in excess of requirements for respiration as the oxygen concentration in the water medium after one hour of incubation was higher than the initial oxygen level. For larger medusae this was not the case, since respiration in the darkness consumed more oxygen than was produced in the light during the same time period. While these results indicate different photosynthesis/respiration ratios for medusae of different sizes, the actual rates of photosynthesis in room lighting probably under estimates the rate which occurs in natural lighting in the estuary.

The rate of photosynthesis is also dependent on the concentration of available carbon dioxide (McGilvery, 1975). As shown in Figure 1 the rate of oxygen production was higher for the small medusae than for bigger medusae. The smaller animal has a greater surface area: volume (SA: V) ratio, which allows carbon dioxide to diffuse through the tissues of the animal at a faster rate, becoming more readily available to the zooxanthellae (Firth, 1996). When medusae were held in darkness, the oxygen concentration in the water medium decreased, indicating that oxygen was consumed by the medusae and its zooxanthellae. In contrast to the pattern of oxygen production, the rate of oxygen consumption per gram wet weight was higher for the bigger medusae than for small animals.

Zooxanthellae in $P$. punctata medusae are located in the epidermal tissues of the bell and oral arms. In the small medusae they occur in similar size groups or clusters of cells. Each group is, presumably, the products of cell division of isolated cells in the ephyra. After cell division, the new cells accumulate in the position of the original cells. Eventually the clusters of cells merge and appear as strands. Zooxanthellae do not occur deep in the thick tissue of the bell. This may explain the observation that the highest concentration of chlorophyll- $a$ per millilitre of homogenate medusae was seen in smaller animals which have the greatest surface area/volume ratio (Table 1). Although large medusae appear more darkly coloured by zooxanthellae than small medusae, a larger proportion of their total mass beneath the epidermis contains no zooxanthellae. 
As oxygen is a by-product of photosynthesis, a high rate of oxygen production would be expected to be followed by a high rate of carbohydrate production. Although the result was not statistically different $(p<0.01)$, the amount of DOC released during one hour incubation in room lighting was greater than when medusae were held in darkness. This suggests that photosynthates translocated from zooxanthellae to medusae of $P$. punctata exceeded the basic needs of the animal host and that exudation of DOC continued after photosynthesis had ceased. Study by McCloskey et al (1994) showed that translocated carbon of $12.69 \mathrm{mg}$ $\mathrm{C}$ day $^{-1}$ should be more than sufficient to support animal respiratory requirements $(6.22$ $\left.\mathrm{mg} \mathrm{C} \mathrm{day}{ }^{-1}\right)$ and daily growth $\left(1.21 \mathrm{mg} \mathrm{C}\right.$ day $^{-}$ $\left.{ }^{1}\right)$ in Mastigias sp. from Palau Lagoon. They suggested that the surplus of $5.26 \mathrm{mg} \mathrm{C}$ day $^{-1}$ contributes to the excess carbon in the lagoon ecotype.

The reported rate of dissolved organic carbon release for Aurelia aurita with a wet weight ranging between 38 to $251 \mathrm{~g}$ in the Skagerrak Gullmars Fjorde, Sweden was 1.2 mg C medusae ${ }^{-1}$ day $^{-1}$ (Hansson and Norman, 1995). The average DOC released by $P$. punctata with wet mass ranging between $4-45$ $\mathrm{g}$ during one hour incubation in room lighting

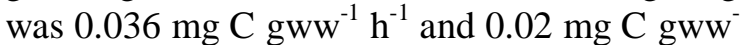
${ }^{1} \mathrm{~h}^{-1}$ for another one hour incubation in darkness. Assuming 14 hours of daylight during summer, the daily DOC released by the medusae are $0.49 \mathrm{mg} \mathrm{C} \mathrm{gww}^{-1}$ during the day and $0.19 \mathrm{mg} \mathrm{C}$ $\mathrm{gww}^{-1}$ during night. It means that the individual medusae of $4-6.8$ grams produced DOC about $27.44 \mathrm{mg} \mathrm{C} \mathrm{day}^{-1}$ and the largest medusae used in this study $(45 \mathrm{~g})$ produced DOC $308.7 \mathrm{mg} \mathrm{C}$ day $^{-1}$. It is clear that the symbiotic medusae of $P$.punctata can individually contribute much more dissolved organic carbon to the water than can individual Aurelia aurita which have no algal symbiont. Carbon fixed through photosynthesis by zooxanthellae and translocated to the animal host, combined with carbon obtained from feeding by the host, provides $P$. punctata with a carbon reserve which can be used for mucus secretion and released as DOC.
The mucus exuded by gelatinous zooplankton has long been recognised as a type of primary production (Hamner et al 1975; Hanson and Norman, 1995). This primary production is then available as an energy source for other organisms. In the Swan estuary, secretion of DOC by $P$. punctata would contribute to a microbial loop and support part of the estuarine food web. The extent and significance of this contribution would depend on the total abundance of $P$. punctata. Where a dense population occurs the contribution may be significant.

\section{Acknowledgment}

The present study was undertaken while the author was an M.Sc. student at the School of Environmental Biology Curtin University of Technology, Perth Western Australia. I am indebted and would like to thank Dr. Rob Rippingale for his suggestions and corrections on the manuscript. Special thank to my family for their very valuable support during my study.

\section{References}

Alldredge, A.L. 1976. Discarded appendicularian houses as sources of food, surface habitats, and particulate organic matter in planktonic environments. J. Limnol. and Oceanog., vol. 21 no. 1 , pp $14-22$.

Colemann, A. 1987. Biomass distribution and related aspects of the two jellyfish species in the Swan river estuary' (unpublished student report). School of Environmental Biology, Curtin University of Technology, Perth Australia.

Coles, S.L. and Strachmann, R. 1973. Observation on coral mucus "flocs" and their potential trophic significance. J. Limnol. and Oceanog., vol. 18, pp 673 - 678.

Falkowski, P.G., Dubinsky, Z., Muscatine, L. and Porter, J.W. 1984. Light and the bioenergetics of a symbiotic coral. J. BioScience, vol. 34, pp 705 - 709 . 
Firth, A. 1996. Mucus exudates of Phyllorhiza punctata : Dissolved organic carbon release in the Swan-Canning estuary (unpublished student report). School of Environmental Biology, Curtin University of Technology, Perth, Australia.

Fitt, W.K., Pardy, R.L. and Littler, M.M. 1982 Photosynthesis, respiration, and contribution to community productivity of the symbiotic sea anemone Anthopleura elegantissima (Brandt,1835). J. Exp. Mar. Biol. and Ecol., vol. 61 , pp 213 - 232

Hansson, L.J. and Norman, B. 1995. Release of dissolved organic carbon (DOC) by the scyphozoan jellyfish Aurelia aurita and its potentia influence on the production of planktonic bacteria. J. Mar. Biol., vol. 121, pp 527 532.

Hamner, W.M., Madin, L.P., Alldredge, A.L., Gilmer, R.W and Hamner, P.P. 1975. Underwater observations of gelatinous zooplankton: Sampling problems, feeding biology, and behaviour. J. Limnol. and Oceanog., vol. 20 pp 907-917.

Hoegh-Guldberg, O. and Hinde, R. 1986. Studies on a nudibranceh that contains zooxanthellae. Photosynthesis, respiration and translocation of newly fixed carbon by zooxanthellae in Pteraeolidia ianthina. Proc. R. Soc. London, Ser. B, vol. 228, pp 493 - 509.

Hofmann, D.K. and Kremer, B.P. 1981. Carbon metabolism and strobilation in Cassiopea andromeda (Cnidaria : Scyphozoa) significance of endo-symbiotic dinoflagellates. J. Mar. Biol., vol. 65, pp 2533.

ISO 10260. 1992. Water Quality Measurement of Biochemical Parameters, Spectrometric Determination of The Chlorophyll- $a$ Concentration. 10260 (1st Ed.). International Standards Organisation.

Kremer, B.P., Costello, J. and Canino, M. 1990 Significance of photosynthetics endosymbionts to the carbon budget of the scyphomedusa Linuche unguiculata. J. Limnol. and Oceanog., vol. 35, no. 3, pp 609-624.
Larsson, U., and Hagström, A. 1982. Phytoplankton exudate release as an energy source for the growth of pelagic bacteria. J. Mar. Biol., vol.52, pp 199 - 206.

McCloskey, L.R., Muscatine, L. and Wilkerson, F.P. 1994. Daily photosynthesis, respiration, and carbon budgets in tropical marine jellyfish (Mastigias sp.). J. Mar. Biol., vol. 119, pp 13-22.

McCloskey, L.R. and Muscatine, L. 1984 Production and respiration in the Red Sea coral Styllophora pistillata as a function of depht. Proc. R. Soc. London, Ser. B, vol. 222, pp 215 - 230.

McGilvery, R.W. 1975. Biochemical Concepts. W.B. Saunders Company. USA

Mulvay, P. 1988. Oxygen production and related aspects of Phyllorhiza punctata in the Swan river estuary (unpublished student report). School of Environmental Biology, Curtin University of Technology, Perth, Australia.

Muscatine, L., Falowski, P.G., Dubinsky, Z., Cook, P.A. and McCloskey, L.R. 1989. The effect of external nutrient resources on the population dynamics of zooxanthellae in a reef coral. Proc. R. Soc. London, Ser. B, vol. 236, pp $311-324$.

Porter, J.W., Muscatine, L., Dubinsky, Z. and Falkowski, P.G. 1984. Primary production and photoadapatation in light and shade-adapted coral, Styllopora pistillata. Proc. R. Soc. London, Ser. B, vol. 222, pp 161-180.

Schneider, G. 1989. The common jellyfish Aurelia aurita : standing stock, excretion and nutrient regeneration in the Kiel Bight, Western Baltic. J. Mar. Biol., vol. 100, pp 507-514.

Sondergaard, M., Hansen, B. and Markager, S. 1995. Dynamics of dissolved organic carbon lability in a eutrophic lake. J. Limnol. and Oceanog., vol. 40 no.1, pp 46 - 54. 